\title{
Burden of Ovine Fasiolosis in Sherka Woreda Arsi, Ethiopia
}

Yoseph Cherinet Megerssa', Tafa Bekele Jima², Yemsrach Miressa Diriba ${ }^{3}$ and Fanos Tadesse W/Mariyam ${ }^{1}$

${ }^{1}$ College of Veterinary Medicine and Agriculture, Addis Ababa University, Ethiopia

${ }^{2}$ Sherka Woreda Office of Livestock and Fisheries Development, Ethiopia

${ }^{3}$ Akaki Woreda Office of Livestock and Fisheries Development, Ethiopia

\begin{abstract}
Fasciolosis is an important helminthic infection causing economic losses due to morbidity and mortality thereby contributing to loss in productivity to livestock industry in Ethiopia. A cross sectional study was, therefore, conducted from December 2015 to April 2016 to determine the prevalence of ovine fasciolosis in four peasant associations in Shirka Woreda, Arsi, Ethiopia. Sedimentation technique was employed to detect Fasciola eggs during the study. A total of 384 sheep were involved in the study amongst which 118 were found to be positive with an overall prevalence of 30.70 per cent. Zenbabahella, Hanu Jawe, Sole Ferekesa and HelaTijoSero peasant associations (PAs) accounted for $35,30.8,34.8$ and 23.076 per cent, respectively. The prevalence of fasciolosis was associated with different variables. Young sheep $(31.62 \%)$ showed higher prevalence rate than adult sheep $(29.6 \%)$. Prevalence of fasciolosis by sex was $35 \%$ and $29.2 \%$ in male and female, respectively. In addition, sheep with poor body condition $(34 \%)$ showed higher prevalence than their counterparts. Over all, none of the variables has shown statistical difference $(p>0.05)$. Therefore, based on the above information ovine fasciolosis was prevalent in the studied areas and could be potential basis for economic loss in these areas. Thus strategies aimed at the parasite and its intermediate host as well appropriate grazing management practices in the study area are recommended.
\end{abstract}

Keywords: Fasiolosis; Sherka Woreda; Ovine; Prevalence

\section{Introduction}

In Africa the largest livestock population has been reported in Ethiopia, with an anticipated population of 26.10 million sheep, 21.70 million goats, 47.50 million cattle, 1 million camels and 39.60 million chickens [1]. Small ruminants play a major role in sustaining house hold stability by serving as sources of meat, milk, skin and generate income. Besides they play traditional social and religious roles [2]. In Ethiopia sheep are the dominant livestock providing up to $63 \%$ of income and $23 \%$ of the food subsistence value obtained from livestock production [3]. Regardless of the large size of sheep population and high potential of productivity in the country, the contribution of this sub-sector to national economy is relatively low due to multitude of constraining factors including malnutrition, diseases, improper healthcare and other management problems [4]. The annual loss due to ovine fasciolosis in central Ethiopia was estimated to be 48.4 million Ethiopian Birr of which 48.8, 46.5 and 4.7\% were due to loss of productivity, mortality and liver condemnation, respectively [5].

Parasitic diseases are the common infections that affect productivity in small ruminants [6,7]. Vast number of parasitic diseases is incriminated to play a harmful effect for production of small ruminants leading to serious economic loss [8-10]. One of the helminthosis that causes immense direct and indirect losses especially in domestic ruminates is fasciolosis $[5,11]$. It is one of the most common helminth infections of ruminants in different parts of the world particularly in its sub-clinical forms $[12,13]$. Sub-clinical forms can cause reduced feed efficiency, weight gains, milk production, reproductive performance, carcass quality and condemnation of livers at slaughter [14]. In domestic ruminants Fasciola species are commonly found as a cause for liver fluke disease particularly in temperate parts of the world. Their life cycle requires the existence of a suitable snail intermediate host in which development of miracidium through metacercariae (infective stage) occurs. The factors that favour the production of metacercariae necessary for outbreaks of fasciolosis includes temperature $\left(\geq 10^{\circ} \mathrm{C}\right)$, availability of snail habitat and moisture [15]. The two species usually implicated in causing the disease are F. hepatica and F. gigantica
[16]. The incidence of the disease has increased in the last few years as a possible consequence of changes in the global climate. Future predictions also suggest that this trend is likely to continue [17].

Though a lot of research work has been done on the prevalence and economic significance of ovine fasciolosis in Ethiopia, so far has no information has been published on ovine fasciolosis in the present study areas where the local farmers consider sheep an important asset. Hence the current study aimed to determine the prevalence of ovine fasciolosis and associated factors in Sherka district, Arsi Zone, Ethiopia.

\section{Materials and Methods}

\section{Study area}

The study area is found in south Eastern Oromia regional state in Arsi zone which is located $265 \mathrm{~km}$ south East of Addis Ababa. Its altitude is between $1500-3400 \mathrm{~m}$ with an average altitude of $2450 \mathrm{~m}$ above mean sea level. The average temperature is $18^{\circ} \mathrm{C}$ which varies between $10^{\circ} \mathrm{C}$ to $25^{\circ} \mathrm{C}$, with an annual average rain fall of around 1000 $\mathrm{mm}$. The livestock population of the district is estimated at 214111 cattle, 50220 sheep, 47203 goats, 15255 horse, 20819 donkeys, 8899 mules, 96363 chickens and 2557 beehive colonies [18]

\section{Study animals and sampling method}

Indigenous sheep kept under traditional extensive management

*Corresponding author: Yoseph Cherinet Megerssa, College of Veterinary Medicine and Agriculture, Addis Ababa University, Addis Ababa, Ethiopia Tel: +251911804383; E-mail: yoseph.cherinet@aau.edu.et

Received January 17, 2017; Accepted February 09, 2017; Published February 11,2017

Citation: Megerssa YC, Jima TB, Diriba YM, W/Mariyam FT (2017) Burden of Ovine Fasiolosis in Sherka Woreda Arsi, Ethiopia. J Vet Sci Technol 8: 426. doi: 10.4172/2157-7579.1000426

Copyright: (c) 2017 Megerssa YC, et al. This is an open-access article distributed under the terms of the Creative Commons Attribution License, which permits unrestricted use, distribution, and reproduction in any medium, provided the original author and source are credited. 
system were used for the study and were distributed in different groups according to the body conditions, sex and age. The Sample size was determined according to the formula given by Thrusfied with a $50 \%$ expected prevalence (considering no previous study was undertaken), 95\% confidence level and 5\% precision [19].

Sampling technique: Four PAs namely: Zenbabahela, Hanu Jawe, Sole Ferekasa and Hella Tijo Sero were selected by considering the population size of sheep in the area. Individual animals were selected using simple random sampling technique. Accordingly, the sample size for each PAs was determined based on proportional allocation (Table 1).

Body condition scoring: Body condition of each animal was determined based on the criteria set by Thompson and Meyer [20]. Using the 5 point scale ( $1=$ very thin to $5=$ obese) animal were visually assessed followed by palpation of the area around the lumbar vertebrae between the back of the ribs and the front of the pelvic bones. However, for convenience, sheep were classified into groups with poor and good body conditions.

Determination of age: The age classification was based on dentition as indicated by Vatta et al. was conveniently categorized as adults and young [21].

\section{Sample collection, transportation and examination}

Faecal samples were collected directly from sheep and placed in sampling bottles and preserved in $10 \%$ formalin. Sample was taken to Asella regional laboratory after labeling with animal identification, age, sex, owner name and site of sample collection. Carpological examination was performed to detect Fasciola eggs in the faeces by using the standard sedimentation technique described by Gupta and Singla [22].

\section{Statistical Analysis}

Prevalence was defined as the percentage of sheep positive for Fasciola eggs. Chi-square $\left(\chi^{2}\right)$ was used to measure the association of fasciolosis with variables using SPSS V.15. $\mathrm{P}<0.05$ was considered as statistically significant.

\section{Results}

Over all prevalence of fasciolosis in the study was $30.75 \%(n=118)$. The prevalence of fasciolosis in the four PAs was 35, 30.8, 34.8 and
23.08\% for Zenbabahella, Hanu Jawe, Sole Ferekesa and HelaTijo Sero, respectively. Prevalence rate among young (31.6\%) and adult (29.6\%) animals was compared but was not statistically significant $(\mathrm{p}>0.05)$. The overall prevalence of fasciolosis in male and female sheep was $35 \%$ and $29.2 \%$, respectively. Although the prevalence was relatively higher in male sheep the difference was not statistically significant $(\mathrm{p}>0.05)$. The prevalence of fasciolosis in sheep with poor body condition was $34 \%$ while in those with good body condition was $27.8 \%$. The difference in the prevalence among the two groups in body condition score was not statistically significant ( $\mathrm{p}>0.05)$ (Table 2 ).

\section{Discussion}

The overall prevalence of fasciolosis in the study areas was $30.7 \%$. The finding was in agreement with Dinka [23] who reported prevalence of $32.7 \%$ in Asella. The prevalence of fasciolosis in this study was higher than the prevalence of $14.6 \%$ reported in Hirna [24], 13.4\% in Nekemte [25] and $13.2 \%$ in middle awash river basin. The prevalence in the current study was lower than the one reported in Kemisse, $49 \%$ [26], in Holeta 53\% [27], Eastern Gojam 63\% [28] and in western Shoa $73 \%$. The variation in prevalence might be due to the differences in rain fall, temperature, moisture, humidity, soil and other ecological factors that could influence the parasite lifecycle as well as the efforts exerted towards the control of the infection. No statistically significant difference was observed in the prevalence of fasciolosis in males and females. Aseged, Ahmed et al. and Ayalew also reported the absence of significant difference in the prevalence between the sexes $[5,26,29]$. The possible explanation for this could be due to similar exposure of the sheep in grazing areas irrespective of their sex. In the current study young sheep showed relatively higher prevalence than adult. Similar findings were reported by Eyerusalem et al. and Michael [30-32]. The possible explanation might be the repeated exposure to fluke infection that might cause development of certain level of immunity in the adults in contrast to younger ones, as a result hampering the establishment of infection in the adults.

The results of the study showed that higher prevalence of fasciolosis in sheep with poor body condition than in the animals with good body condition. Similar to our finding Molelegne et al., Yemisirach and Mekonnen also found that sheep with poor body condition had higher prevalence than their counterparts [33]. This could be explained by the fact that sheep with poor body conditions are less resistant and are consequently vulnerable to infectious diseases [34].

\begin{tabular}{|c|c|c|}
\hline Peasant Association & Sheep population size & Proportional allocation \\
\hline Zenbabahella & 2000 & 100 \\
\hline Hanu Jawe & 1040 & 52 \\
\hline Sole Ferekasa & 2300 \\
\hline Hela Tijo Sero & 2340 \\
\hline Total & $\mathbf{7 6 8 0}$ & 115 \\
\hline
\end{tabular}

Table 1: Peasant association versus distribution of sheep in the study.

\begin{tabular}{|c|c|c|c|c|c|}
\hline \multicolumn{2}{|c|}{ Category } & \multirow{2}{*}{$\begin{array}{c}\text { Number of sheep } \\
100 \\
52 \\
115 \\
117\end{array}$} & \multirow{2}{*}{$\begin{array}{c}\text { No. positive } \\
35 \\
16 \\
40 \\
27\end{array}$} & \multirow{2}{*}{$\begin{array}{c}\text { Prevalence (\%) } \\
35 \\
30.8 \\
34.8 \\
23.1\end{array}$} & \multirow{2}{*}{$\begin{array}{c}\mathbf{X}^{2} \boldsymbol{p} \text { value } \\
0.194\end{array}$} \\
\hline PAs & $\begin{array}{c}\text { Zenbabahella } \\
\text { Hanu Jawe } \\
\text { Sole Ferekesa } \\
\text { HelaTijo Sero }\end{array}$ & & & & \\
\hline Age & $\begin{array}{l}\text { Young } \\
\text { Adult }\end{array}$ & $\begin{array}{l}215 \\
169\end{array}$ & $\begin{array}{l}68 \\
50\end{array}$ & $\begin{array}{l}31.62 \\
29.60\end{array}$ & 0.375 \\
\hline Sex & $\begin{array}{c}\text { Male } \\
\text { Female }\end{array}$ & $\begin{array}{l}103 \\
281\end{array}$ & $\begin{array}{l}36 \\
82\end{array}$ & $\begin{array}{c}35 \\
29.2\end{array}$ & 0.168 \\
\hline Body condition & $\begin{array}{l}\text { Poor } \\
\text { Good }\end{array}$ & $\begin{array}{l}215 \\
169\end{array}$ & $\begin{array}{l}73 \\
45\end{array}$ & $\begin{array}{c}34 \\
27.80\end{array}$ & 0.068 \\
\hline
\end{tabular}

Table 2: Prevalence of ovine fasciolosis in relation to peasant associations, age, sex and body condition. 


\section{Conclusion and Recommendations}

The study has investigated the prevalence of ovine fasciolosis in SherkaWoreda Arsi, Ethiopia in four peasant associations and found overall prevalence of $30.7 \%$. It was noted that fasciolosis was relatively higher in the sheep with poor body condition score than their counterparts. However, immunoassays together with faecal examinations need to be conducted to have more accurate data on the burden of ovine fasciolosis. Strategies aimed at deworming in the study areas have to be implemented to minimize the effect of fasciolosis in sheep. Training has to be given to farmers about the prevention and control of fasciolosis. Studies on the epidemiology of fasciolosis in order to expand and implement disease investigation and control strategy should be conducted.

\section{Acknowledgments}

It is our pleasure to thank Addis Ababa University, Shirka woreda livestock, fisheries and animal health office and owners of study animals in the peasant association for their support to accomplish the study.

\section{Author's Contribution}

Yoseph Cherinet Megerssa designed the study and helped in analyzing the data. Tafa Bekele Jima collected samples, done the laboratory analysis and completed his BSc degree using the data. Fanos Tadesse W/Mariyam and Yemsrach Miressa Diriba assist in analysis and editing of the manuscript.

\section{Conflict of Interests}

No conflict of interest or relevant financial disclosure.

\section{References}

1. CSA (2009) Agricultural survey report on livestock, poultry and bee hives population in private peasant holding in Addis Ababa.

2. Alemayehu Z, Fletcher I (1995) Small ruminant productivity in the contro Ethiopia mixed farming system. Institute of Agricultural Proceeding 4: 19411947.

3. Zelalem A, Fletcher I (1991) Small ruminant productivity in the control Ethiopian mixed farming system. In: IAR. Ababa, Ethiopia $4^{\text {th }}$ Notional livestock Improvement conference 99: 141-147.

4. Ademosun AA (1992) Constraints and prospects for small ruminant research and development in Africa. In: Small Ruminant Research and Development in Africa. Proceedings of the 2nd Biennial Conference SRNET, AICC, Arusha, Tanzania, pp: 1-5.

5. Ahmed EF, Markvichitr K, Tumwasorn S, Koonawootrittriron S, Choothesa A, et al. (2007) Prevalence of fasciola species infections of sheep in the middle awash river basin, Ethiopia. South East Asian J Trop Med Public Health 38: 51-57.

6. Haileleul N (2002) Study on prevalence of GIT helminths of small ruminants in and around Wolayta Gupta Soddo, Southern Ethiopia. DVM Thesis. Faculty of Veterinary Medicine, Addis Ababa University, DebreZeit, Ethiopia.

7. Tesfaheywet $T$ (2012) Helminthosis of sheep and goats in and around Haramaya south-eastern Ethiopia. J Vet Med Anim Healt 4: 48-55.

8. Teklay B (1991) Epidemiology of endoparasites of small ruminants in subSaharan Africa Proceedings of fourth National Livestock Improvement conference. Addis Ababa, Ethiopia, 13-15 November 7-11.

9. Singla LD (1995) A note on sub-clinical gastro-intestinal parasitism in sheep and goats in Ludhiana and Faridkot districts of Punjab. Indian Vet Med J 19: 61-62.

10. Singh R, Bal MS, Singla LD, Kaur $P$ (2016) Detection of anthelmintic resistance in sheep and goat against albendazole by faecal egg count reduction test. $\mathrm{J}$ Parasit Dis, pp: 1-4.

11. Yadeta B (1994) Epidemiology of bovine and ovine fasciolosis and distribution of its snail intermediate host in western Showa. DVM Thesis, Faculty of Veterinary Medicine, Addis Ababa University, Debrezeit, Ethiopia.

12. Adem A (1994) Prevalence of bovine fasciolosis: a preliminary survey around Zeway region, Showa Ethiopia. DVM Thesis, Faculty of Veterinary Medicine,
Addis Ababa University, Debrezeit, Ethiopia.

13. Mas-Coma S, Bargaes MD, Valero MA (2005) Fasciolosis and other plantborne trematode zoonosis. Int J Parasitol 35: 1255-1278.

14. Pfukenyi DM, Mukaratirwa S, Willingham AL, Monrad J (2006) Epidemiological studies of Fasciola gigantica infections in cattle in the high yield and low yield communal grazing areas of Zimbabwe. J Vet Res. 73: 37-51.

15. Urquhart GM, Armour J, Duncan JL, Dunn AM, Jennings FW (1996) Veterinary Parasitology. 2nd edn., Oxford, UK. Longman Scientific and Technical Press, pp: 100-109.

16. Okewol EA, Ogundipe GAT, Adejinmi JO, Olaniyan AO (2000) Clinical evaluation of three chemoprophylactic regimes against ovine helminthosis in a Fasciola endemic farm in Ibadan, Nigeria. Israel J Vet Med 56: 15-28.

17. Fairweather I (2011) Reducing the future threat from liver fluke: realistic prospect or quixotic fantasy. Vet Parasitol. 180: 133-143.

18. Shirk Wereda Livestock and Fish Resource Office Annual Report of 2015.

19. Thrusfield M (2007) Veterinary Epidemiology. 3rd edn. Blackwell Science Ltd., London, UK, pp: 228-246.

20. Thompson JM, Meyer H (1992) Body condition scoring of sheep. Oregon State University, Extension Service, pp: 1-6.

21. Vatta AF, Abbot MA, Villiers JF, Gumede SA, Harrison LJS, et al. (1988) Seasonal prevalence of protostrongylid and Dictyocaulus species of lungworms in Awassi sheep in North-West Syria. Trop Anim Health Prod 20: 187-189.

22. Gupta SK, Singla LD (2012) Diagnostic trends in parasitic diseases of animals In: Veterinary Diagnostics: Current Trends. Gupta RP, Garg SR, Nehra V, Lather D (eds.), Satish Serial Publishing House, Delhi, pp: 81-112.

23. Dinka A (1996) Preliminary study on prevalence of fasciolosis in small ruminants in and around Assela (Arsi). DVM Thesis, Faculty of Veterinary Medicine, Addis Ababa University, Debrezeit, Ethiopia.

24. Henok M, Mekonnen A (2011) Study on prevalence and risk factors of fasciolosis in small ruminants in and around Hirna Town, Ethiopia. Global Veterinaria 7: 497-501.

25. Wassise M (1995) Prevalence of bovine and ovine fasciolosis a preliminary survey in Nekemte and its surround areas. DVM Thesis, Faculty of Veterinary Medicine, Addis Ababa University, Debrezeit, Ethiopia.

26. Molalegne B, Nuradis I, Nahili A (2010) Study on the prevalence of Ovine fascolosis and around Dawa- Cheffa Kemissie. Afr J Agr Res 5: 2981-2985.

27. Yilma J (1995) Study on ovine fasciolosis and other helminthes parasites at Holeta. DVM Thesis, Faculty of Veterinary Medicine, Addis Ababa University, Debrezeit, Ethiopia.

28. Beyazen C (1995) Preliminary study on epidemiology of fasciolosis in eastern Gojjam region, Ethiopia. DVM Thesis, Faculty of Veterinary Medicine, Addis Ababa University, Debrezeit, Ethiopia.

29. Aseged G (1990) Studies on the ecology of helminth parasites in naturally infected indigenous sheep in Awassa, Southern Ethiopia. PhD Thesis, JustusLeipzig University, Germany, p: 176.

30. Ayalew T (1994) Preliminary survey of sheep helminthiasis in Kimbibit district North Shoa. 8th Conference of the Ethiopian Veterinary Association, Addis Ababa, Ethiopia. Addis Ababa: Ethiopian Veterinary Association, pp: 86-94.

31. Eyerusalem G, Zgabeher, Yeshitila A, Bekele M (2012) Prevalence of ovine fasciolosis in Adigrat, North East Ethiopia. Global Veterinaria 9: 92-96.

32. Micheal A (2004) Infection prevalence of ovine fasciolosis in irrigation schemes along the upper Awash river Basin and effects of strategic anthelmenthic treatment in selected up stream areas. MSc Thesis in Biology (Biomedical Science), Addis Ababa University, Ethiopia.

33. Yemisrach A, Mekonnen A (2012) An abattoir study on the prevalence of fasciolosis in cattle, sheep and goats in DebreZeit town, Ethiopia. Global Veterinaria 8: 308-314.

34. Radositis OM, Blood DC, Gray CC (2000) Veterinary Medicine a text book of disease of cattle, sheep, pigs, goats and horses. 8th edn., pp: 1230-1235. 